\title{
HERA OF KANATHOS AND THE LUDOVISI THRONE.
}

\section{[Plate V.]}

OF all the interpretations of the Ludovisi throne it is generally agreed that none is entirely convincing. For that reason any new suggestions that I have to bring forward here should only be interpreted as an attempt to indicate a fresh line of investigation that may perhaps lead to a more complete understanding of this most difficult of archaeological problems.

At the outset we are faced with the almost universally accepted view that the subject of the Ludovisi throne is the Birth of Aphrodite, with representatives of the cult or devotees shown on the side panels. Once this is admitted the explanation of the details of scene becomes a matter of purest academical or technical dispute. Similarly, the important corollary follows that the Boston counterpart, whatever we may think of its date or style, represents but other aspects, clearly more complicated, of the Aphrodite cult.

The interpretation that I have to bring forward here, however, by challenging the first and principal assumption, renders me liable to the charge that I am wilfully indulging in that worst of learned vices-the deliberate circulation of startling theories. I should therefore perhaps explain that the interpretation I propose here did not arise from any determined effort on my part to solve the problem of the Ludovisi throne, but rather originated gradually from the correlation of a variety of evidence which reached me quite independently of the main problem. ${ }^{1}$

On the site of Tiryns in the Hellenic stratum the remains of a temple of Hera were found during the course of the German excavations of 1909-10. In and round the site a large number of terracotta figures were found. Most of these figures represented the goddess Hera in various forms. There is, however, a large series representing a very peculiar, and in many ways unique, type. The goddess is shown as either seated or standing, crowned and with heavy necklaces. In front of her breast she holds a square cloth. In almost every case the cloth stands clear of the breasts, or perhaps just touches. The artist appears to have made the breasts of separate pellets of clay and added

\footnotetext{
1 During the spring of this year I had occasion to visit the Museum at Nauplia. The terracottas, of which I show photographs below, impressed me at the time as bearing some sort of relation to the Ludovisi throne. A re-reading of Pausanias, coupled with a close examination of the throne early in June,

suggested what this relation might be. I nust here express my indebtedness to Mr. A. W. Lawrence of New College, Oxford, for his help and collaboration. It was he who called my attention to the importance of the passage in Pausanias here dealt with (ii. 38. 2). 
them to the body. He similarly made the square cloth out of a separate flat piece of clay and attached it to the hands and body. (Fig. 1.) The square cloth is not a part of the garment worn by the figure, and so cannot be intended to be the overfall of a peplos. In each case the cloth stands clear of the figure at each corner and is a clear-cut rectangular piece of fabric.

The question immediately presents itself as to what these figures represent and what is the special meaning and purpose of the square cloth. . No evidence as to an explanation is forthcoming from the site itself and we
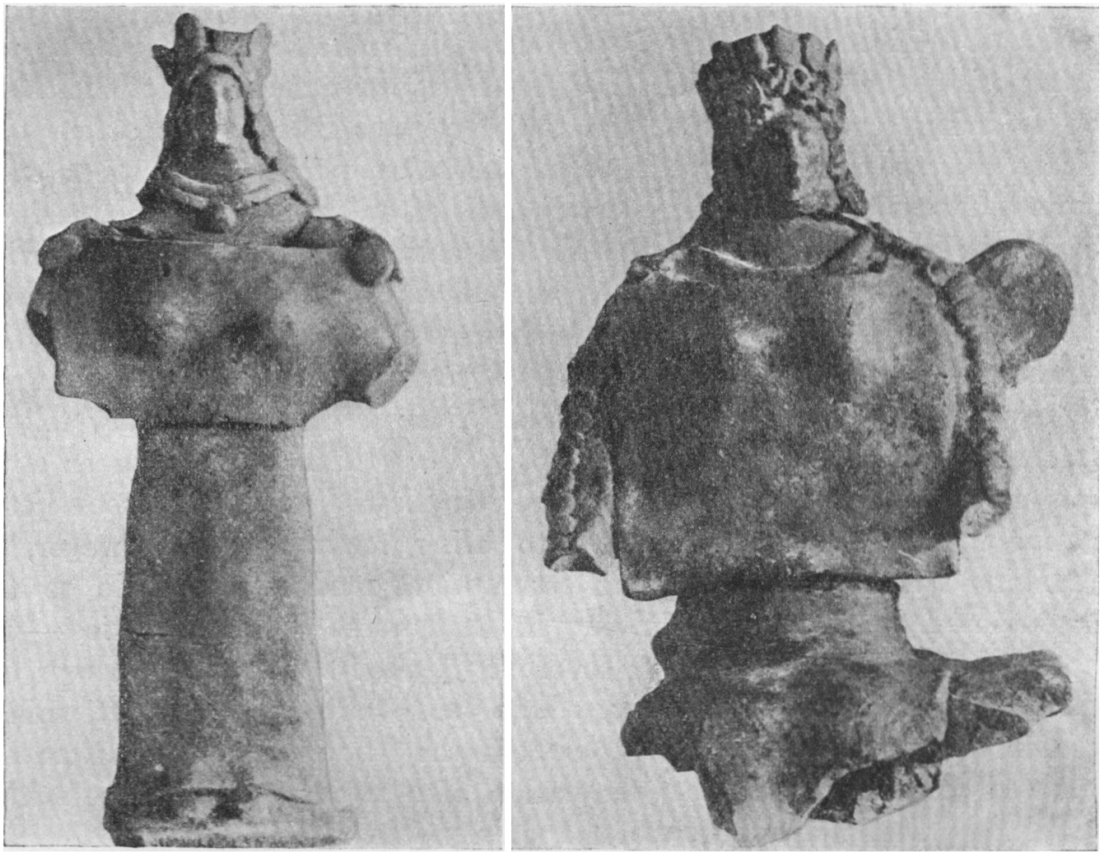

Fig. 1.--Terkacoqta Figures of Hera from the Temple at Tiryns.

must look elsewhere. Most of the best examples of this type of figurine belong to the first half of the fifth century; it is, therefore, perhaps, not inappropriate to refer to Pindar for passages that may throw light upon their meaning. In the tenth Nemean Ode the poet sings of Hebe:

$$
\begin{aligned}
& \kappa a \tau \text { ' "O } \mathrm{O} \nu \mu \pi{ }^{\prime}
\end{aligned}
$$

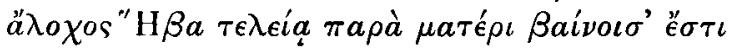

$$
\begin{aligned}
& \kappa a \lambda \lambda i \sigma \tau a \theta \epsilon \hat{\omega} \nu \text {. }
\end{aligned}
$$

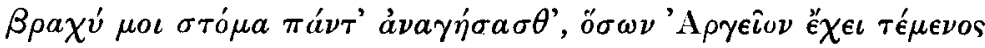

$$
\begin{aligned}
& \mu \circ \hat{\imath} \rho a \nu \dot{\epsilon} \sigma \lambda \hat{\omega} \nu \text {. }
\end{aligned}
$$

'Hebe, fairest of goddesses, walketh for ever in Olympus beside her mother Hera, who maketh marriage perfect. My mouth is of small measure 
to tell all the story, to wit, all the fair things of which the holy precinct of Argos hath a share.' 2

In this passage Pindar clearly refers to the function of Hera as $\tau \epsilon \lambda \epsilon i a$, the goddess of Matrons. In the sixth Olympian Ode he refers to the

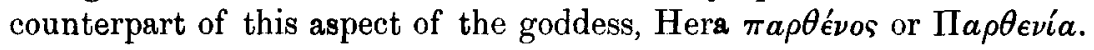

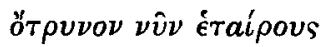

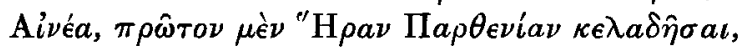

'Now bid thy comrades, Aeneas, first to sound the praises of Hera as the maiden goddess.'

This exhortation is addressed to the people of Stymphalus in Arcadia, a day's journey from Argos.

That these passages refer to two definite cults of Hera as opposed to simple aspects of a literary nature is clear from other evidence. Thus Pausanias states that there was a temple of Hera near Hermione in the Argolid, ${ }^{3}$ and from Stephanus Byzantinus (s.v. ${ }^{\mathrm{C}} \mathrm{E} \rho \mu \boldsymbol{i}^{\prime} \omega \nu$ ) it seems clear that the temple was of Hera Parthenos. In the sume way it is clear from the description of Arcadia ${ }^{4}$ in Pausanias that there was there a definite cult of Hera $\tau \epsilon \lambda \epsilon i a$ such as is suggested by the passage from Pindar quoted above. Finally, to make it beyond question that these were definite cults, Pausanias mentions the temple of Hera $\tau \epsilon \lambda \in i a$ at Plataea, ${ }^{5}$ in which were a statue of a standing figure of Hera by Praxiteles and a seated figure of Hera $\nu v \mu \phi \epsilon v o-$ $\mu \epsilon ́ \nu \eta$ by Callimachus.

Unfortunately we have no representation in art that can be definitely identified either as Hera $\tau \epsilon \lambda \epsilon i a$ or as Hera $\pi a \rho \theta$ évos, unless we identify the Hera in the metope from Selinus as Hera $\tau \epsilon \lambda \epsilon i a$ or $\nu v \mu \phi \epsilon v o \mu e^{\nu} \eta$.

In trying to identify the Hera of the Tiryns figures we are therefore driven to adopt the rather unsatisfactory methods of a priori reasoning to a certain extent. The fact that the figures in every case bear a cloth in front of the breasts and that they all seem to represent a fully grown and stately woman, seated or standing in a dignified attitude, suggests that the cloth, which is the centre of interest of the figures, is emblematic of matronhood. Immaturity might well be nude, maturity should be garbed. The fact that behind the cloth the breasts are nude only serves to emphasise the distinction. In a word the cloth, which is clearly the distinguishing cult-sign in these statuettes, is the symbol of Hera $\tau \in \lambda \in i a$ as opposed to

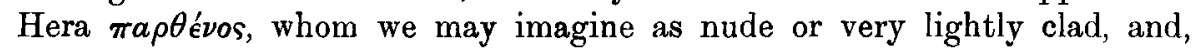
above all, with her breasts uncovered. The figurines thus represent Hera $\tau \epsilon \lambda \epsilon i a$, whose worship we know to have been popular in neighbouring Stymphalus side by side with that of Hera $\pi a \rho \theta$ é $\nu o s$.

* From Sir John Sandys' translation. For the meaning of re入eía see Class. Rev. xv. p. 446. Mr. Bayfield denies that the word

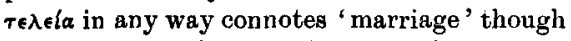
he admits that "H $\rho \alpha \tau \in \lambda \epsilon i a$ was to Greeks the goddess of marriage rites. Sir John Sandys is clearly not in agreement with him in regard to the meaning of $\tau \in \lambda \in i$. $\alpha$. For another re-

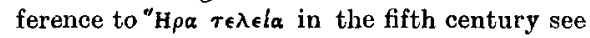
Aeschylus, Ehom. 214.

3 Paus. ii. 36.

' Id. viii. $22,2$.

5 Id. ix. 2. 5 . 
So much for the figures and the square cloth which is their distinguishing characteristic. ${ }^{6}$

Pausanias, in his description of the Argolid, ${ }^{7}$ says that at Nauplia there are harbours and a temple of Poseidon, and ' a spring called Kanathos where, so say the Argives, Hera bathes every year and, by so doing, becomes a maiden; it is this story which is of the secrets connected with the rites they perform to Hera.' However much more he may know about this story and the rites he leaves unspoken, in respect for the secrecy of the cult. It is obvious, nevertheless, that this particular cult must have been of the utmost importance in the worship of Hera on account of its fundamental nature and because it seems to be a third type of cult in which the other cults of Hera $\tau \epsilon \lambda \epsilon i a$ and Hera $\pi a \rho \theta \theta^{\prime} \nu o s$, sufficiently important in themselves, were to a certain extent combined. The paucity of records concerning it is

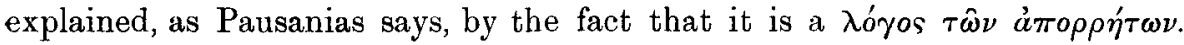

We can connect these two groups of facts, then, in this way. At Tiryns we find a cult of Hera which emphasises her qualities of matron in clearly marked and evidently intentional distinction from her qualities as maiden. Within a mile of Tiryns was a sacred spring in which Hera the matron was transformed each year into Hera the maiden.

What, then, is the bearing of the argument upon the Ludovisi throne?

In the light of the evidence set forth above $I$ put forward the suggestion that in the central panel of the throne we have a representation of Hera being raised from the spring of Kanathos by two attendants, priestesses or maidens. Before being let down into the waters she had upon her breast the symbolic cloth of matronhood of the same type as that worn by the Hera of the Tiryns sanctuary. On emerging from the spring the attendants let down the cloth and disclosed the breasts, as though to say, "This is Hera the maiden that was Hera the matron.' The fact that Hera is not actually nude seems to be a concession to tradition, according to which, in art, Hera is never nude. The pebble-strewn ground upon which the attendants are standing is far more suited to the banks of a spring than to a Greek seashore, which would be better typified by sand or rocks.

In regard to the detail of the figures and drapery one or two points need discussion. The cloth which is being lowered from the breasts is clearly of thick and heavy material. So too are the cloths held up by the Hera figures from Tiryns. The hands of the Hera go under the further arms of the attendant and grip the outer side of their shoulders in the same way as their hands grip the outer sides of Hera's shoulders. The breasts of the Hera would thus naturally be drawn widely apart by the strain, so that it seems unwise to attribute this wide spacing of the breasts entirely to the archaism of the sculpture. The thin gauze-like chiton of Hera clings to her figure because she has emerged from the water.

Once this interpretation is adopted the figures on the side panels

6 Some of these figures, such as that shown

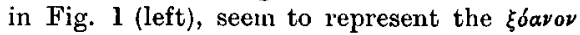
which Peirasos set up at Tiryns and which was seen later by Pausanias at the Heraeum (ii. 17,5),

7 Paus. ii. 38. 2, 
present no special difficulties. They clearly represent either votaries or

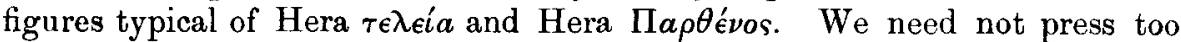
closely for a decision any more than we need decide that the Maidens of the Acropolis at Athens are votaries or priestesses or merely suitable offerings to Athena. They were maiden statues offered to a maiden goddess, ${ }^{8}$ and our figures of the panels are matron and maiden figures characteristic of the two aspects of Hera.

Ovid ${ }^{9}$ in his account of the Falerian festival to Juno, which was copied from that at Argos, describes the procession in honour of the goddess:

' ubi praesonuit solemni tibia cantu.'

The flute was thus not unsuited to votaries of Hera. Our little maid of the side panel, piping solemnly to herself, can hardly be more than seventeen years of age, and the suggestion of Mr. Caskey ${ }^{10}$ and others that she is a young courtesan seems as groundless as it is unfair to the artist of the throne. Mr. Caskey's argument that his interpretation as to her humble origin and calling and, as he puts it, her 'lower social stratum,' is evident from the thickness of her wrists and ankles, which, he says, compare unfavourably with those of the draped lady of the other panel, is indeed remarkable; it belongs, I think, to a realm of sculptural snobbery as far removed from the delicate genius of the 'Precursors' as it should be from modern criticism. It has the additional demerit of being untrue in point of fact.

The appropriateness of the interpretation of the lady of the other panel

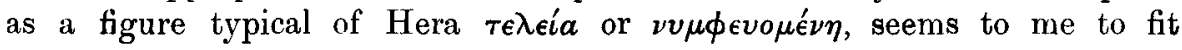
consistently into the interpretation of the monument as a whole. The garments she wears are closely paralleled by the garments of the Hera on the metope from Selinus. Her occupation as a burner of incense in no way conflicts with her identification as a matron typical of the cult of Hera te $\lambda \epsilon i a$. The Maidens of the Acropolis at Athens bear pomegranates and doves as votaries would do, and yet they are neither votaries nor yet priestesses. There is a certain confusion of idea or absence of clear definition that makes them at once votaries and typical and suitable offerings in themselves. So too with the maid and matron of the Ludovisi relief, who are each engaged in occupations characteristic of the Goddess $\tau \epsilon \lambda \epsilon i a$ and $\pi a \rho \theta$ évos.

At this point critics will say, 'But what about the Boston counterpart? ${ }^{11}$ How does it fit in, if it does at all, to this interpretation?' I can only echo their doubt. It apparently does not fit in. This is perhaps a serious flaw in my interpretation. But I have merely let my evidence carry me to my conclusion. I have tried hard not to let preconceived theories squeeze the evidence into a Procrustean bed of theory so that it will fit well. I can,

- See G. Dickins, Acropolis Museum Catalogue, i. p. 33.

$A$ mor. iii. 13.

${ }^{10}$ A.J.A., 1918, p. 118.

11 One objection to the attribution of the Boston throne to the early fifth century that has not, I think, been noted before is that the wing feathers of the Eros are not of an early type but resemble rather the wing feathers from the Parthenon pediment or from the Nike Temple balustrade. (Cf. wing fragments nos. 176, 208, 3473-4, 3478-80 in the Acropolis museum and see Prandtl in Ath. Mitth. 1908, Pl. II. 10.) 


\section{HERA OF KANATHOS AND THE LUDOVISI THRONE}

therefore, only regret that the Boston counterpart remains without an interpretation similar to that of the Ludovisi throne. But this at once suggests that to call it a 'counterpart' is in itself a preconceived theory. Is it essential, because it is architecturally and structurally similar to the Ludovisi throne, to assume that it is necessarily a part of that throne? That in itself compels those who would interpret the one to accommodate their interpretation to suit the other; and that is bad critical method.

S. Casson. 